\title{
Association between alcohol consumption and dietary supplement intake of students from the University of Sarajevo
}

Nafija Serdarević1,2* , Arzija Pašalić르 Eldina Smječanin², Vedran Đido², Refet Gojak³, Muris Pecar², Fatima Jusupovićc, Dijana Avdićc Namik Trtak², Eldad Kaljićc , Amila Jaganjac², Bakir Katana²,

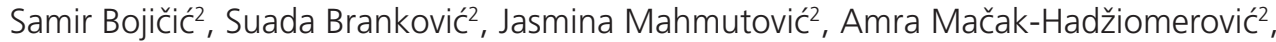
Gordana Manić², Redžo Čausević , Adnan Šehić2, Ema Gojak², Almedina Hajrović , Amela Salihovićc ${ }^{2}$ Minela Husejinović Velagić ${ }^{2}$, Ehlimana Pecar ${ }^{4}$, Deni Selimović ${ }^{5}$

${ }^{1}$ Institute for Clinical Biochemistry and Immunology, Clinical Center University of Sarajevo, Sarajevo, Bosnia and Herzegovina, ${ }^{2}$ Faculty of Health Studies, University of Sarajevo, Sarajevo, Bosnia and Herzegovina, ${ }^{3}$ Infectology Clinic, Clinical Center University of Sarajevo, Sarajevo, Bosnia and Herzegovina, ${ }^{4}$ Health Center Sarajevo, Sarajevo, Bosnia and Herzegovina, ${ }^{5}$ Private Practice "Praxis" Dr. Pecar, Sarajevo, Bosnia and Herzegovina

\section{ABSTRACT}

Introduction: Dietary supplements are an important source of vitamins and minerals that may help prevent several disease-causing biological pathways involved in one-carbon metabolism, including the suppression of cell proliferation, oxidative stress, nitric oxide synthesis, and angiogenesis. The present study aimed to assess the association between the intake of folate, Vitamin B6, Vitamin B12, and minerals and the consumption of alcohol among university students.

Methods: This study was participated by students aged 19-22 years from the University of Sarajevo between 2017 and 2018. Using a questionnaire, we interviewed in a week them to collect information regarding age, socio-economic status, alcohol consumption, and dietary supplement intake. Then, we investigated the association between the baseline intake of folate, B vitamins, and minerals and that of alcohol consumption.

Results: Most students consumed Vitamin B supplements (32\%) and folic acid (10\%). Dietary multivitamins and minerals were less prevalent in more than a year, accounting for $186(23.9 \%)$ and $174(24.3 \%)$ students, respectively, than those in less than a year. In a year, $<20 \%$ of students consumed multivitamins $129(16.6 \%)$ and minerals 116 (15.3\%). Meanwhile, 256 (27.1\%) students consumed alcohol. The Chi-square test of independence showed that drinking habits and the intake of such dietary supplements had no association $(p>0.05)$.

Conclusion: An extremely low percentage of the participating students in Canton Sarajevo used dietary supplements of Vitamin B, folate, multivitamins, and minerals. Moreover, alcohol consumption and dietary supplement intake were not associated. Further research is needed to establish the best cost-effective public health system to achieve a sufficient intake of dietary supplements.

Key words: Folate; Vitamin B; multivitamins; minerals; students

*Corresponding author: Nafija Serdarević, Institute for Clinical Biochemistry and Immunology, Clinical Center University of Sarajevo and Faculty of Health Studies, Sarajevo, Bosnia and Herzegovina. Phone: +387-33-444-113. Fax: +387-33-444-113. E-mail: serdarevicnafija@yahoo.com 


\section{INTRODUCTION}

Millions of people worldwide use dietary supplements. Dietary supplements represent an important source of essential nutrients $(1,2)$. In Germany, around $21 \%$ of young people, as well as $66 \%$ of American students, $68 \%$ of Serbian students, and $43 \%$ of Malaysians students, used dietary supplements (3-6). Alcohol intake is one of the common habits that may impair the biological actions of folate. Ethanol and its metabolites appear to reduce the circulating folate levels and interfere with some of its biochemical actions (7). Alcohol may alter the status of folate and/or Vitamin B12 due to their critical roles in one-carbon metabolism $(8,9)$. Low folate intake and high alcohol intake increase the risk of colorectal cancer (10-12). In this cycle, the folate- and Vitamin B12-dependent enzyme methionine synthase stands at the junction of two key processes responsible for maintaining DNA integrity, and these processes are the synthesis of purines and thymine, and methylation reactions through $S$-adenosylmethionine. When folate and/or Vitamin B12 is depleted, one-carbon metabolism may be altered, and possibly, procarcinogenic effects, including uracil incorporation and increased susceptibility of DNA to strand breaks, aberrations in the methylation of DNA, and disruption of DNA repair, may occur. Total homocysteine (tHcy) is a cardiovascular disease (CVD) risk factor. It is elevated in patients who have chronic alcoholism and experienced falls following alcohol withdrawal; therefore, alcohol may have a deleterious effect on health by increasing the tHcy levels. Homocysteine is regulated through a series of pathways that are dependent on B vitamins, particularly folate $(8,9)$. Associations between moderate alcohol consumption and tHcy concentrations and between alcohol, folate, and chronic disease risk have been extensively reported (13-21). This study aimed to determine the prevalence of usage of dietary supplements containing Vitamin B12, folic acid, multivitamins, and minerals in students from the University of Sarajevo, and to assess their alcohol consumption and its relationship with supplement intake.

\section{METHODS}

\section{Subjects}

We investigated students aged 19-22 years from the Faculty of Health Studies, Faculty of Electrical
Engineering, School of Economics and Business, and Faculty of Pedagogy at the University of Sarajevo between 2017 and 2018. The participants were interviewed in a week to collect information on age, socio-economic status, and alcohol and dietary supplement intake. Subjects who were currently diagnosed with diseases such as diabetes, cancer, CVD, and kidney disease; were taking medications that can affect the folate metabolism; and did not finish their survey were excluded from the study. A total of 960 students participated.

\section{Methods}

In accordance with our questionnaire, we interviewed $1^{\text {st }}$ and $4^{\text {th }}$-year students coming from the above-mentioned health and non-medical faculties. We examined their general characteristics, alcohol intake, dietary supplement use, and lifestyle. The questionnaire contains questions such as "Do you take supplements of Vitamin B or folic acid?" and "How long do you use multivitamins or minerals?" The answers were "yes or no" for the first question and " 1 year," "more than 1 year," and " $<1$ year" for the second one (Figures 1 and 2).

\section{Statistical analysis}

After returning all completed questionnaires, the data were analyzed by the Statistical Package for Social Sciences (SPSS) version 13.0 software (SPSS Inc., Chicago, USA) and Microsoft Excel. The absolute (n) and relative frequencies (\%) were determined and then cross-tabulated with the sex of participants, faculty attended, year of the study, status of studies, vitamin and mineral intake, place of residence (town; village; and suburb), parents' educational attainment, alcohol drinking, and the relationship between alcohol consumption and vitamin or mineral intake. The differences between the study groups were tested for significance by Pearson's Chi-square test. The differences between the study groups were considered significant if the probability of zero hypothesis $(p \leq 0.05)$.

\section{RESULTS}

In our study, we interviewed 960 students from the University of Sarajevo, with an average age of $20.4 \pm 2.1$ years. The investigation was based on a 


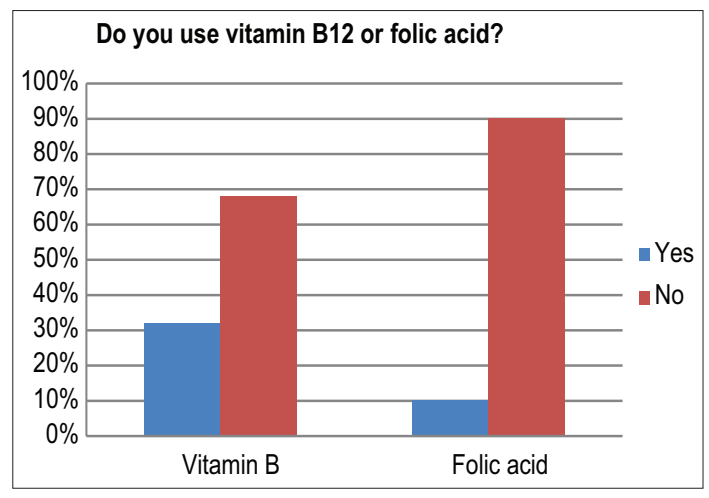

FIGURE 1. Frequency of consuming Vitamin B and folic acid supplements.

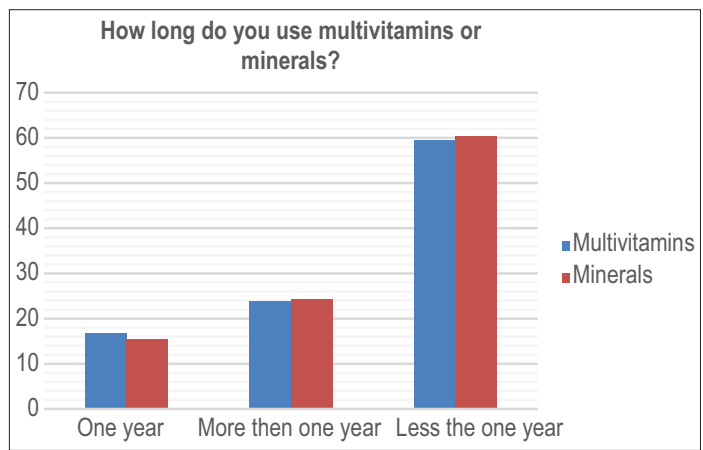

FIGURE 2. Prevalence of consuming vitamin and mineral supplements.

questionnaire about dietary supplement usage, time of supplement use, consumption of alcohol, and relationship between alcohol consumption and supplement intake. Most of the study participants were female, accounting for 656 (68.3\%), whereas male students accounted for 304 (31.7\%). Meanwhile, $38.1 \%, 24.7 \%, 30.4 \%$, and $6.8 \%$ of students belonged to the Faculty of Health Studies, Faculty of Electrical Engineering, School of Economics and Business, and Faculty of Pedagogy, respectively. Furthermore, $593(61.8 \%)$ students were still in the $1^{\text {st }}$-year level, and $367(38.2 \%)$ were in the $4^{\text {th }}$-year level. Out of the 960 students, only 256 (27.1\%) consumed alcohol. With regard to the frequency of intake of vitamin and mineral supplements, most of the students did not take Vitamin B (642, 68\%) and folic acid $(843,90 \%)$ supplements. Conversely, in terms of prevalence, more than half of the student population took multivitamin 462 (59.5\%) and mineral 458 (60.4\%) supplements in <1 year, but dropped to $186(23.9 \%)$ and 174 (24.3\%), respectively, in more than a year. In addition, $<20 \%$ of students took multivitamins $129(16.6 \%)$ and minerals $116(15.3 \%)$ in 1 year. The most used dietary supplements were Vitamin B (32\%) and multivitamins (16.6-59.5\%). The results are shown in The questionnaire consists of five questions relating to socio-economic status. We found that during classes, $662(69 \%)$ students lived in an apartment, $187(19.5 \%)$ in a rented apartment, and $111(11.6 \%)$ in dormitories. More than half of the student population lived with their families 648 (67.5\%), some lived with their friends 230 (24\%), and a few lived alone 82 (8.5\%). Many lived in towns 639 (66.6\%), some lived in the suburbs 259 (27\%), while a few lived in a village $62(6.5 \%)$. Parents of students were mostly employed 759 (80.6\%), some were unemployed $95(10.1 \%)$, and the rest were retired 88 (9.3\%). The faculty education has $443(47.5 \%)$ parents, and high school education has 517 (52.5\%) parents (Table 1).

Of the 960 students, 256 consumed alcohol, while 689 did not. Chi-square test of independence revealed that drinking habits and $\mathrm{B}$ vitamin supplement use were not associated $(p=0.369)$. Multivitamin and mineral intakes were also not associated with alcohol consumption $(p>0.05)$. Moreover, drinking habits and folic acid supplement use are not associated $(p=0.924)$ (Table 2).

\section{DISCUSSION}

Dietary supplements are an important source of essential nutrients; hence, millions of people worldwide use dietary supplements. The European Union (EU) Directive 2002/46/EC was the first dietary supplement regulatory act in the EU countries. As mentioned earlier, in Germany, around $21 \%$ of young people used dietary supplements, as well as $66 \%$ of American students, $68 \%$ of Serbian students, and $43 \%$ of Malaysian students (3-6). In the current study, approximately $32 \%$ and $10 \%$ of students took Vitamin B and folic acid supplements, respectively. In general, folate deficiency is most often the result of decreased food intake and is more common in developing and socioeconomically 
TABLE 1. Socio-economic status of students

\begin{tabular}{lcc}
\hline Question & $\mathrm{n}$ & $\%$ \\
\hline Where do you live during classes? & & \\
$\quad$ Apartment & 662 & 69.0 \\
Rented apartment & 187 & 19.5 \\
$\quad$ Dorms & 111 & 11.6 \\
Who do you live with? & & \\
$\quad$ Family & 648 & 67.5 \\
Alone & 82 & 8.5 \\
With friends & 230 & 24.0 \\
What kind of place do you live? & & \\
Town & 639 & 6.6 \\
$\quad$ Suburb & 259 & 27.0 \\
$\quad$ Village & 62 & 6.5 \\
What is the working status of your parents? & & \\
$\quad$ Employed & 759 & 80.6 \\
Unemployed & 95 & 10.1 \\
$\quad$ Retired & 88 & 9.3 \\
What is your parents' educational attainment? & & \\
$\quad$ College education & 443 & 47.5 \\
High school education & 517 & 52.5 \\
\hline
\end{tabular}

distressed countries. In contrast, more than half of the student population took multivitamins and minerals in $<1$ year, but at 1 year, only $<20 \%$ of students consumed these supplements. The most used dietary supplement was Vitamin B, followed by multivitamins and then multiminerals.

Recently, a high percentage (49.6\%) use of nutritional and herbal supplements was found among college students in Qatar. In Bahrain and Saudi Arabia, the general population and patients with diabetes used complementary and alternative medicines, respectively $(22,23)$. Young people are particularly vulnerable to the effects of poor nutrition, including nutrient deficiencies (24). The prevalence of dietary supplement use among the studied university students was $30.5 \%$, which is similar to the results in Korea (31.3\%), Middle East (39\%), and Tehran (33\%). In addition, many similar studies reported that multivitamins and multivitamin-mineral combinations are the most frequently used dietary supplements among students (25-27). Socio-economic status is related to the use of dietary supplements. The US NHANES 2001-2002 and NHANES III 1988-1994 surveys showed that supplement users were more affluent than those who were not. In
TABLE 2. Relationship between alcohol drinking (yes/no) and consumption of dietary supplements in students

\begin{tabular}{|c|c|c|c|c|}
\hline \multirow[t]{2}{*}{ Dietary supplements } & & \multicolumn{2}{|c|}{ Alcohol } & \multirow{2}{*}{$\frac{\chi 2 \text { test }}{p}$} \\
\hline & & Yes & No & \\
\hline \multicolumn{5}{|l|}{ Vitamin B } \\
\hline \multirow[t]{2}{*}{ Yes } & $\mathrm{n}$ & 87 & 211 & 0.369 \\
\hline & $\%$ & 34.3 & 31.2 & \\
\hline \multirow[t]{2}{*}{ No } & $\mathrm{n}$ & 167 & 466 & \\
\hline & $\%$ & 65.7 & 68.8 & \\
\hline \multicolumn{5}{|l|}{ Folic acid } \\
\hline \multirow[t]{2}{*}{ Yes } & $\mathrm{n}$ & 26 & 68 & 0.924 \\
\hline & $\%$ & 10.3 & 10.1 & \\
\hline \multirow[t]{2}{*}{ No } & $\mathrm{n}$ & 226 & 605 & \\
\hline & $\%$ & 89.7 & 89.9 & \\
\hline \multicolumn{5}{|l|}{ Multivitamins } \\
\hline \multirow{2}{*}{$\begin{array}{l}\text { More than } \\
1 \text { year }\end{array}$} & $\mathrm{n}$ & 57 & 125 & 0.413 \\
\hline & $\%$ & 26.6 & 22.6 & \\
\hline \multirow[t]{2}{*}{1 year } & $\mathrm{n}$ & 31 & 95 & \\
\hline & $\%$ & 14.5 & 17.2 & \\
\hline \multirow[t]{2}{*}{$<1$ year } & $\mathrm{n}$ & 126 & 332 & \\
\hline & $\%$ & 58.9 & 60.1 & \\
\hline \multicolumn{5}{|l|}{ Minerals } \\
\hline \multirow{2}{*}{$\begin{array}{l}\text { More than } \\
1 \text { year }\end{array}$} & $\mathrm{n}$ & 59 & 120 & 0.123 \\
\hline & $\%$ & 27.8 & 22.4 & \\
\hline \multirow[t]{2}{*}{1 year } & $\mathrm{n}$ & 25 & 89 & \\
\hline & $\%$ & 11.8 & 16.6 & \\
\hline \multirow[t]{2}{*}{$<1$ year } & $\mathrm{n}$ & 128 & 327 & \\
\hline & $\%$ & 60.4 & 61.0 & \\
\hline
\end{tabular}

another study, French women who were supplement users were more likely to live alone, to have few or no children, to live in the Mediterranean region, and to live in larger cities. Meanwhile, dietary supplement use is related to higher educational attainment $(28,29)$.

In our study, most of the students lived with parents and in towns, while the least lived alone and in dorms. More than half of the parent population were employed and had attained a high school education.

Many studies found that people who consume less alcohol were more likely to take supplements; however, a study from Canada did not find an association between alcohol consumption and dietary supplement use, consistent with the current study. These discrepancies may be due to the type of alcohol consumed; previous studies found positive 
associations for wine consumption but not for beer consumption $(30,31)$.

In our study, less than half of the student population consumed alcohol. As revealed by the Chisquare test of independence, drinking habits and Vitamin B supplement use were not associated. Around two-thirds of the students did not take this supplement with or without alcohol intake. Similarly, drinking habits and folic acid supplement use were not associated. Cigarette smoking and alcohol intake are two common habits that may impair the biologic actions of folate. With the presence of ethanol and its metabolites, the circulating folate levels could be reduced, and some of its biochemical actions could be interfered (32). Considering that we lack information about low or moderate alcohol consumption, the results cannot be considered an adequate means of describing the relationship between alcohol consumption and folate and Vitamin B status.

\section{CONCLUSION}

Only few students consumed Vitamin B, which was the most used dietary supplement, and folic acid supplement. In $<1$ year, more than half of the student population consumed multivitamins and minerals. Alcohol consumption and multivitamin or mineral supplement intake were not associated. Likewise, drinking habits and folic acid supplement use were not associated. Moreover, the study emphasizes the need for increased awareness and basic knowledge on the side effects and source of reliable information for the use of dietary supplements. Expert health-care practitioners are also needed in the related field for proper and timely guidance in the general population.

\section{ACKNOWLEDGMENTS}

The research project was done with the support of Ministry for Education, Science and Youth of Canton Sarajevo, Bosnia and Herzegovina. We are very thankful for good cooperation with deans, professors, and students of Faculty of Health Studies, Faculty of Electrical Engineering, School of Economics and Business, and Faculty of Pedagogy at the University of Sarajevo who participated in this research.

\section{FUNDING}

This research was done with a research project grant sponsored from the Ministry for Education, Science and Youth, Canton SSarajevo, Bosnia and Herzegovina. Project: "KNOWLEDGE AND IMPORTANCE OF VITAMIN B12 AND B6 SOURCE IN STUDENT POPULATION FOR THE PREVENTION OF ATEROSCROLLES" Number: 11-05-14-26743-1/18.

\section{CONFLICTS OF INTEREST}

The author(s) confirm that this article content has no conflicts of interest.

\section{REFERENCES}

1. Archer SL, Stamler J, Moag-Stahlberg A, Van Horn L, Garside D, Chan Q, et al. Association of dietary supplement use with specific micronutrient intakes among middle-aged American men and women: The INTERMAP study. J Am Diet Assoc 2005;105:1106-14.

https://doi.org/10.1016/j.jada.2005.04.010.

2. National Institues of Health. Office of Dietary Supplements Dietary Supplement Health and Education Act of 1994. Public Low 103-417. 108 Stat 4325. Available from: https://www.ods.od.nih.gov/About/DSHEA Wording.aspx. [Last accessed on 2018 Jan 18]

3. Federal Research Center for Nutrition and Food Nationale Verzehrs Studie II. Ergebnisbericht, Teil 2. Available from: https://www.mri.bund.de/fileadmin/MRI/Institute/EV/NVSII_Abschlussbericht_Teil_2.pdf. [Last accessed on 2018 Jan 28].

4. Murphy SP, White KK, Park SY, Sharma S. Multivitamin-multimineral supplements' effect on total nutrient intake. Am J Clin Nutr 2007;85:280s-4.

5. Stanojević-Ristić Z, Stević S, Rašić J, Valjarević D, Dejanović M, Valjarević A. Influence of pharmacological education on perceptions, attitudes and use of dietary supplements by medical students. BMC Complement Altern Med 2017;17:527.

https://doi.org/10.1186/s12906-017-2031-6.

6. Al-Naggar RA, Chen R. Prevalence of vitamin-mineral supplements use and associated factors among young Malaysians. Asian Pac J Cancer Prev 2011;12:1023-9.

7. Giovannucci E, Stampfer MJ, Colditz GA, Rimm EB, Trichopoulos D, Rosner BA, et al. Folate, methionine, and alcohol intake and risk of colorectal adenoma. J Natl Cancer Inst 1993;85:875-84. https://doi.org/10.1093/jnci/85.11.875.

8. Bailey LB, Gregory JF $3^{\text {rd }}$. Folate metabolism and requirements. J Nutr 1999;129:779-82

9. Choi SW, Mason JB. Folate and carcinogenesis: An integrated scheme. J Nutr 2000;130:129-32.

10. Longnecker MP. Alcoholic beverage consumption in relation to risk of breast cancer: Meta-analysis and review. Cancer Causes Control 1994;5:73-82. https://doi.org/10.1007/bf01830729.

11. La Vecchia C, Negri E, Pelucchi C, Franceschi S. Dietary folate and colorectal cancer. Int J Cancer 2002;102:545-7.

https://doi.org/10.1002/ijc.10720.

12. Giovannucci E. Epidemiologic studies of folate and colorectal neoplasia: A review. J Nutr 2002;132:2350S-5. https://doi.org/10.1093/jn/132.8.2350s 
13. Serdarević N, Begić L, Mulaomerovic-Softić A. The concentration of homocysteine in patients after ischemic brain stroke and vascular dementia. J Health Sci 2011;1:4-9.

https://doi.org/10.17532/jhsci.2011.91.

14. Serdarevic N, Begic L, Mulaomerovic-Softic A. The determination of serum homocysteine and lipid levels at patients with ischemic stroke and vascular dementia. Biochim Clin 2013;167:s375. The 20 th IFCC-EFCC European Congress of Clinical Chemistry and Laboratory Medicine, EUROMEDLAB, 19-23 May 2013, in Milano, Italy. https://doi.org/10.17532/jhsci.2011.91.

15. Serdarevic N, Begic L, Mulaomerovic-Softic A. Clin chem. Vol. 627. Berlin: EUROMEDLAB; The serum homocysteine concentration at patients with cerebrovascular diseases; $\mathrm{p}$. ppS1 p0853.

16. Serdarevic N, Begic L, Mulaomerovic-Softic A. Clin chem. Vol. 627. Berlin: EUROMEDLAB; The correlation between homocysteine and uric acid in the acute and convalescent phases after stroke; p. ppS1 p0854. Serdarević N. The Serum Concentration of Homocysteine and Lipids after Ischemic Stroke. $1^{\text {st }}$ Congress of Medical Biochemists of Bosnia and Herzegovina; 2010.

17. Fisekovic S, Serdarevic N, Memic A, Serdarevic R, Sahbegovic S, Kucukalic A. Correlation between serum concentrations of homocysteine, folate and Vitamin B12 in patients with schizophrenia. JHSCI 2011;3:138-144. https://doi.org/10.17532/jhsci.2013.78.

18. Serdarevic N. The serum homocysteine and lipid levels at patients with ischemic stroke and vascular dementia. FASEB J 2013;27:795.

19. Serdarević $N$. The serum homocystein and dyslipidemia at patients with ischemic stroke. PP 66. JNC 2009;110:25.

20. Serdarević N, Begic $L$. The serum homocysteine concentration at haemodialysis patients. HealthMed 2011;5(4):976-81.

21. Al-Faris EA, Al-Rowais N, Mohamed AG, Al-Rukban MO, Al-Kurdi A, Balla Al-Noor MA, et al. Prevalence and pattern of alternative medicine use: The results of a household survey. Ann Saudi Med 2008:28:4-10.

https://doi.org/10.4103/0256-4947.51761.

22. Khalaf AJ, Whitford DL. The use of complementary and alternative medicine by patients with diabetes mellitus in Bahrain: A cross-sectional study. BMC Complement Altern Med 2010;10:35. https://doi.org/10.1186/1472-6882-10-35.

23. Bailey RL, Fulgoni VL $3^{\text {rd }}$, Keast DR, Lentino CV, Dwyer JT. Do dietary supplements improve micronutrient sufficiency in children and adolescents? J
Pediatr 2012;161:837-42.

https://doi.org/10.1016/j.jpeds.2012.05.009.

24. Sotoudeh G, Kabiri S, Yeganeh HS, Koohdani F, Khajehnasiri F, Khosravi S. Predictors of dietary supplement usage among medical interns of Tehran university of medical sciences. J Health Popul Nutr 2015;33:68-75.

25. Alhomoud FK, Basil M, Bondarev A. Knowledge, attitudes and practices (KAP) relating to dietary supplements among health sciences and nonhealth sciences students in one of the universities of United Arab emirates (UAE). J Clin Diagn Res 2016;10:JC05-JC09.

https://doi.org/10.7860/jcdr/2016/19300.8439.

26. Kim SH, Han JH, Keen CL. Vitamin and mineral supplement use by healthy teenagers in Korea: Motivating factors and dietary consequences. Nutrition 2001;17:373-80.

https://doi.org/10.1016/s0899-9007(00)00582-7.

27. Touvier M, Kesse E, Volatier JL, Clavel-Chapelon F, Boutron-Ruault MC. Dietary and cancer-related behaviors of vitamin/mineral dietary supplement users in a large cohort of French women. Eur J Nutr 2006;45:205-14. https://doi.org/10.1007/s00394-006-0587-x.

28. Block G, Jensen CD, Norkus EP, Dalvi TB, Wong LG, McManus JF, et al. Usage patterns, health, and nutritional status of long-term multiple dietary supplement users: A cross-sectional study. Nutr J 2007;6:30.

https://doi.org/10.1186/1475-2891-6-30.

29. Kofoed CL, Christensen J, Dragsted LO, Tjønneland A, Roswall N. Determinants of dietary supplement use-healthy individuals use dietary supplements. Br J Nutr 2015;113:1993-2000.

https://doi.org/10.1017/s0007114515001440.

30. Beitz R, Mensink GB, Hintzpeter B, Fischer B, Erbersdobler HF. Do users of dietary supplements differ from nonusers in their food consumption? Eur J Epidemiol 2004;19:335-41.

https://doi.org/10.1023/b: ejep.0000024698.76843.3b.

31. Giovannucci E, Stampfer MJ, Colditz GA, Rimm EB, Trichopoulos D, Rosner BA, et al. Folate, methionine, and alcohol intake and risk of colorectal adenoma. J Natl Cancer Inst 1993;85:875-84.

https://doi.org/10.1093/jnci/85.11.875.

32. Serdarević N, Katana B, Jaganjac A, Bojičić S, Branković S, Mahmutović J. The cigarette smoking, coffee and supplements intake at students of Sarajevo University. Med Arch 2019;73(2):104-8.

https://doi.org/10.5455/medarh.2019.73.104-108. 